\title{
Elżbieta KRYŃSKA*
}

\section{Elastyczność zatrudnienia w Polsce i w Unii Europejskiej ${ }^{* *}$}

Znaczące miejsce w prowadzonych na gruncie teoretycznym i wynikających z empirii dociekaniach przyczyn powstawania i utrzymywania się nierównowagi na rynku pracy ma jego elastyczność, rozumiana jako zdolność łatwego przystosowywania się do zmieniających warunków. Potrzeba zwiększenia elastyczności rynku pracy jest od dłuższego czasu podnoszona w dyskusjach nad sposobami ograniczania bezrobocia w krajach wysoko rozwiniętych, zwłaszcza w oparciu o doświadczenia USA i niektórych krajów Unii Europejskiej. Potrzeba ta dostrzeżona została również w Polsce ze względu na rosnące bezrobocie, którego jednym ze sposobów ograniczania zdaje się być zwiększenie elastyczności podaży i popytu na pracę. Wiąże się z tym dylemat pojęcia i zakresu elastyczności rynku pracy oraz jej uwarunkowań i konsekwencji.

\section{Interpretacja pojęć kluczowych}

Pojęcie „elastyczności" w istocie odnosi się nie tyle do kategorii rynku pracy jako pewnego abstraktu myślowego, a do trzech jego elementów składowych - podaży, popytu oraz ceny pracy. Widać to wyraźnie przy próbach identyfikacji poszczególnych aspektów elastyczności rynku pracy. Wyodrębnia się bowiem najczęściej [por. Rosenberg 1989, Adnett 1996, Solow 1998, Wiśniewski 1999]:

- elastyczność zatrudnienia (ilościową) oznaczającą zdolność dostosowania liczby zatrudnionych w przedsiębiorstwie i czasu ich pracy do zmieniających się warunków: koniunktury, rentowności, płac realnych, wydajności pracy, wywołanych postępem technicznym i technologicznym czy stwarzanych przez politykę strukturalną państwa;

- elastyczność czasu pracy oznaczającą moźliwość dostosowywania (w ramach ustalonych norm) długości czasu pracy i jego organizacji do potrzeb przedsiębiorstwa, poszczególnych grup pracowników czy wykonywanego zadania;

- elastyczność funkcjonalną wynikającą z rozwoju horyzontalnych wewnętrznych rynków pracy, polegającą na pokonaniu tradycyjnych ograniczeń wykonywania zawodów w wyniku odpowiedniej organizacji pracy - takiej, gdzie w możliwie dużym zakresie zredukowany jest podział pracy;

- Elżbieta Kryńska jest pracownikiem naukowym Uniwersytetu Lódzkiego.

* Artykuł przygotowano na podstawie ekspertyzy wykonanej dla Międzyresortowego Zespołu do Prognozowania Popytu na Pracę pt. „Analiza nowych form zatrudnienia”. 
- elastyczność płac obejmującą proces dostosowywania wysokości i struktury wynagrodzeń do zmian wydajności pracy, rentowności działalności i sytuacji panującej na rynku pracy.

Wyniki dociekań teoretycznych i badań empirycznych wskazują, iż wysoka elastyczność rynku pracy sprzyja zmniejszeniu nierównowagi na nim. Dla polityk rynku pracy realizowanych w UE w latach dziewięćdziesiątych zwiększenie elastyczności stało się jednym ze sposobów ograniczania bezrobocia. Wykorzystano tu w szczególności elastyczność zatrudnienia, funkcjonalną i czasu pracy, opierające się na stosowaniu niestandardowych form zatrudnienia i organizacji pracy, a więc zatrudnienia $w$ innej formie niż tradycyjna.

Wyróżnić można kilka podstawowych kategorii niestandardowych form zatrudnienia i organizacji pracy powodujących uelastycznienie rynku pracy [zob. np. Kühl 1990, Bielensky 1993, Pocztowski 1994, Chobot 1997]:

- Kontraktowanie pracy polegające na odejściu od tradycyjnych długoterminowych umów o pracę i zastąpienie ich kontraktami na pracę chałupniczą, w niepełnym wymiarze czasu, na wykonanie konkretnego zadania itp., w określonych porach roku czy dniach tygodnia, w nietypowych porach dnia. Kontrakty mogą być zawierane przez firmy z pracownikami lub/i innymi firmami. Kontraktowanie pracy charakteryzuje się sprecyzowaniem zadania, które może być wykonywane w domu (w warunkach pracy chałupniczej), bez określenia dziennego limitu godzin, miejsca wykonywania zadania i dyspozycyjności osoby zatrudnionej. Jest to system obniżający koszty pracy przez ograniczenie czasu nieprzepracowanego, umożliwiający zmniejszenie aparatu kontrolnego oraz pozwalający na uniknięcie wydatków na przygotowanie stanowiska pracy oraz systemów bezpieczeństwa i higieny pracy. Kontrakty podpisywane są często na prace nietypowe, występujące okazjonalnie lub wymagające wiedzy specjalistycznej. Wygasają w momencie wykonania zadania lub realizacji założonego celu. Nie pociągają za sobą dalszych zobowiązań ze strony partnerów kontraktu (tak osoby zlecającej, jak i realizującej zlecenie). Kontraktowanie pracy może być formą współpracy między zakładem głównym a wyodrębnionymi (np. w procesach prywatyzacyjnych) zakładami podporządkowanymi.

- Umowy o pracę na czas okresllony występujące w trzech rodzajach: na okres próbny, na czas wykonania określonej pracy czy zadania lub na czas nauki zawodu. Nabierają one coraz większego znaczenia w świecie. Ustawowe ograniczenia ich powtarzalności lub okresu, na które mogą być zawierane wskazują, iż są one dogodną i chętnie stosowaną przez pracodawców formą zatrudnienia pracowników.

- Zatrudnienie w częściowym wymiarze czasu pracy, mniejszym oczywiście niż wymiar pełny. Praca w niepełnym wymiarze jest formą zatrudnienia oferowaną w przypadku braku zapotrzebowania na daną pracę w pełnym wymiarze. Umowa o pracę w niepełnym wymiarze godzin może być zawarta na czas określony (także próbny) albo na czas nieokreślony. Z tej formy zatrudnienia na ogół najczęściej są skłonne korzystać osoby pragnące uzupełnić budżet domowy. 
- Praca dorywcza (tymczasowa) umoźliwiająca dowolne rozbudowywanie lub redukowanie zatrudnienia w firmie, w zależności od koniunktury, w związku z czym mówi się o tzw. „zarządzaniu akordeonowym”.

- Realizacja programów rynku pracy prowadząca do zatrudnienia określonej liczby osób na czas trwania danego programu. Odbywa się w ramach aktywnych form przeciwdziałania bezrobociu, obejmuje zatrudnienie pewnej grupy osób na ściśle określony czas w celu wykonania konkretnego zadania lub w celu przystosowania się pracowników do nowych warunków. Okres trwania programu daje pracodawcy możliwość analizy przydatności zatrudnionych. Programy rynku pracy wiążą się z systemem refundacji kosztów zatrudnienia pracowników przez publiczne służby zatrudnienia.

- Samozatrudnienie pracowników w miejsce zatrudnienia najemnego. W jego ramach prace proste lub wysoko specjalistyczne, nie wymagające nadzoru, mogą być wykonywane przez osoby pracujące na rachunek własny. Polega ono na wydzielaniu części prac wykonywanych w przedsiębiorstwach do realizacji przez pracowników (często wykonujących wcześniej te same zajęcia w warunkach pracy najemnej) pracujących na własny rachunek (np. sprzątanie, proste remonty i tym podobne prace nie wymagające wysokich kwalifikacji, ale również prace projektowe czy doradcze wymagające wysokich kwalifikacji). Pracownicy ci kontynuują więc wykonywanie tych samych czynności na rzecz tego samego pracodawcy. Samozatrudnienie jest formą wykonywania pracy zleconej często na rzecz dotychczasowego pracodawcy, który w wyniku przekształceń lub zmian organizacyjnych doprowadził do pełnego lub częściowego usamodzielnienia się pracowników (bądź jednostek podległych).

- Wypożyczanie pracowników mające charakter trójstronny. Wyraża się zawarciem umowy - subkontraktu między aktualnym pracodawcą, pracownikiem i zakładem wypożyczającym. Umowy te mogą przewidywać wykonanie konkretnego zadania, ekspertyzy czy usługi. Pracownicy są najczęściej zatrudniani na krótkie okresy w pełnym lub niepełnym wymiarze czasu pracy, a po wykonaniu zadania wracają do macierzystego zakładu pracy. Ta forma pracy wiąże się z zatrudnieniem okresowym; po uplywie okresu „wypożyczenia” pracownik wraca do stanu oczekiwania.

- Dzielenie pracy jest formą zatrudnienia dwóch lub większej liczby pracowników na stanowisku pracy przewidzianym przez pracodawcę dla jednego pracobiorcy. Forma ta nabiera znaczenia w okresach kryzysów koniunkturalnych i ma na celu uniknięcie masowych zwolnień. Pracownicy dzielą również wynagrodzenie oraz inne świadczenia związane z pracą, proporcjonalnie do wykonywanych zadań lub według specjalnych ustaleń. Odmianą dzielenia pracy jest redukcja godzin pracy pracowników w celu uniknięcia zwolnień z pracy. Jest to forma dostosowywania się do realiów rynku pracy w warunkach wysokiego bezrobocia i trudności gospodarczych pracodawców.

- Zmienny czas pracy pracowników zatrudnionych na stałe. Ich czas pracy może być róźny i zmieniać się z tygodnia na tydzień, w zależności od po- 
trzeb działalności firmy. System ten powinien powodować lepsze dostosowanie godzin Świadczenia pracy do potrzeb przedsiębiorstwa z jednoczesnym uwzględnieniem preferencji pracowników. U jego podstawy leży ramowo (ustawowo) określona - możliwie jak największa swoboda w decydowaniu o rozkładach czasu pracy.

- Praca na wezwanie oraz praca na telefon - są to formy pracy, w której pracodawca może wezwać pracownika do jej świadczenia w każdym momencie. Może być oparta na kontrakcie określającym warunki zatrudnienia lub umowie określającej minimum i maksimum należności i zobowiązań tak ze strony pracownika, jak ze strony pracodawcy. Pracownik pozostaje do dyspozycji pracodawcy, (np. pełni dyżur w domu) a podejmuje ją w przypadku wezwania.

- Praca w domu oraz telepraca - to formy pracy, których miejscem realizacji nie jest zakład pracy, lecz miejsce wyznaczone przez pracownika. Pracownik wykonuje powierzone zadania, jest z nich rozliczany przez pracodawcę, lecz pozostaje poza jego kontrolą.

Telepraca jest najnowszą formą wykonywania pracy na odległość za pośrednictwem komputera i łączy telefonicznych. Innymi słowy jest to praca wykonywana przy pomocy nowoczesnych technik informatycznych i telekomunikacyjnych, w dowolnej odległości od miejsca, gdzie jest tradycyjnie rozliczana. Oparta jest na systemach tak pełnego, jak i częściowego wymiaru czasu pracy. Umowa z osobą wykonującą swe zadania w ramach telepracy może być również realizowana w formie umowy agencyjnej, koncesji, kontraktu lub działalności gospodarczej. Mogą być nią objęte różne dziedziny działalności.

Jak widać z powyższego zestawienia, niestandardowe - elastyczne formy zatrudnienia i organizacji pracy nie są wobec siebie rozłączne, a zatrudnienie może przybierać cechy jednej lub więcej z nich.

\section{Elastyczne formy zatrudnienia i organizacji pracy w Polsce i w Unii Europejskiej}

Możliwość analizy wdrażania elastycznych form zatrudnienia i organizacji pracy w Polsce jest ograniczona. Szczuplość danych pochodzących z badań ich dotyczących pozwala jedynie na prześledzenie tendencji zmian takich form zatrudnienia, jak: praca w niepełnym wymiarze czasu wraz z motywami jej podejmowania, praca dorywcza, praca na rachunek własny oraz praca w ramach aktywnych programów rynku pracy.

\section{Praca w niepelnym wymiarze czasu}

Informacje o pracy w niepełnym wymiarze czasu pochodzą z badań aktywności ekonomicznej ludności oraz sprawozdań zakładów pracy zatrudniających powyżej pięciu osób, sporządzanych dla GUS. 
Analiza danych zgromadzonym w badaniach aktywności ekonomicznej ludności dotyczących zbiorowości pracujących w niepełnym wymiarze czasu ${ }^{1}$ pozwoliła na sformułowanie następujących wniosków.

1. Udział pracujących w niepełnym wymiarze czasu w zbiorowości pracujących ogółem w badanym okresie kształtował się na średnim poziomie 10,6\%, był stosunkowo stabilny, najwyższy poziom osiągnął w lutym 1997 r. $(11,4 \%)$, najniższy w sierpniu 1997 r. i w sierpniu 1998 r. (10,0\%), wykazując przy tym nieznaczną tendencję malejącą (wykres 1). Udział ten był słabo dodatnio skorelowany z wysokością stopy bezrobocia (współczynnik korelacji 0,44 ).

2. Pracujący w niepełnym wymiarze czasu kierowali się motywami ekonomicznymi i pozaekonomicznymi. Do motywów ekonomicznych zaliczone zostały czynniki związane z zakładem pracy oraz brak możliwości zdobycia pracy w większym wymiarze czasu. Motywy pozaekonomiczne to akceptacja takiego wymiaru czasu pracy, nauka (uzupełnianie kwalifikacji) i przyczyny osobiste (rodzinne).

Wśród motywów podejmowania pracy w niepełnym wymiarze czasu dominowały przyczyny pozaekonomiczne (średnio wskazywało na nie $83 \%$ zbiorowości osób tak pracujących). Udział pracujących w niepełnym wymiarze czasu z przyczyn pozaekonomicznych miał tendencję rosnącą. Był ujemnie skorelowany z poziomem stopy bezrobocia $(-0,676)$.

Wykres 1. Udzial pracujących w niepelnym wymiarze czasu pracy w pracujących (maj 1992-luty 1999)

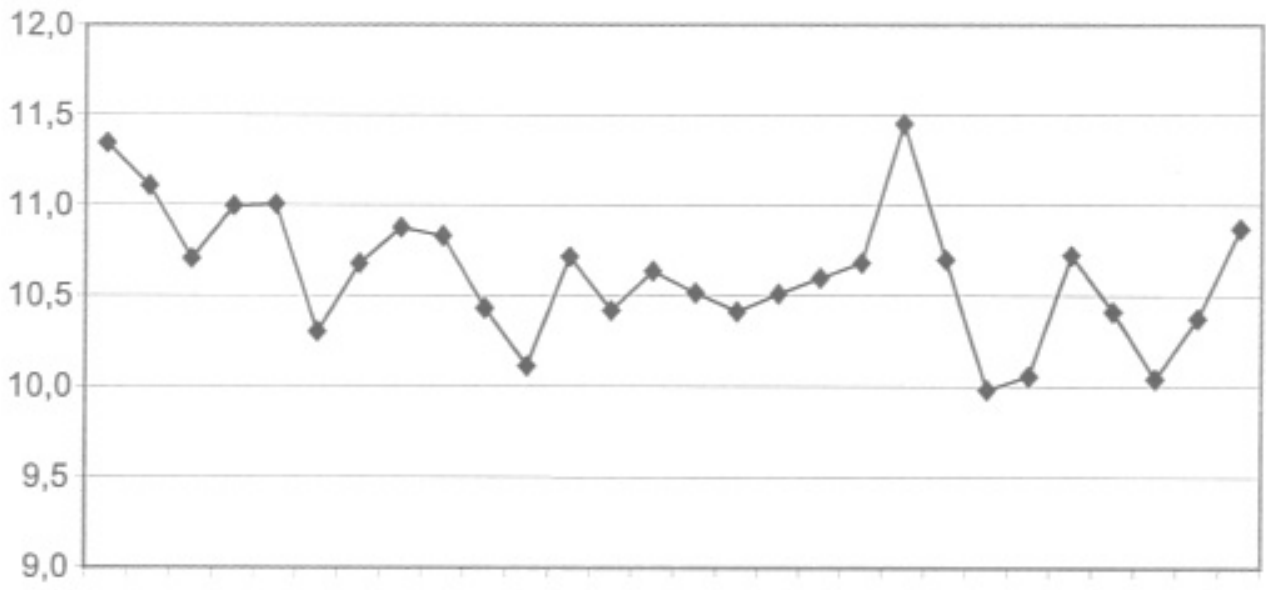

122344567789910111213141516171819202122232425262728

Źródło: Dane BAEL

Udział pracujących w niepełnym wymiarze czasu z przyczyn ekonomicznych kształtował się średnio w badanym okresie na poziomie $17,1 \%$, przy

1 Dane za okres od maja 1992 r. do lutego 1999 r. (28 momentów czasowych) [źródlo: GUS 1999, 1999a]. 
czym miał tendencję malejącą i był dodatnio skorelowany z poziomem stopy bezrobocia (współczynnik korelacji 0,56). Pracujący w niepełnym wymiarze czasu z przyczyn ekonomicznych najczęściej $(63,9 \%)$ wskazywali na brak możliwości zdobycia pracy w większym wymiarze czasu.

3. Podejmowanie pracy w niepełnym wymiarze czasu najczęściej następuje z powodów pozaekonomicznych, a zatem - jak należy domniemywać - jest akceptowane i wynika ze świadomego wyboru, a nie z prób dostosowywania się do trudnej sytuacji na rynku pracy. Wniosek taki potwierdza również niewysoki poziom współczynnika korelacji między udziałem pracujących w niepełnym wymiarze czasu w ogóle pracujących a stopą bezrobocia.

Jak widać - odsetek pracujących w niepełnym wymiarze czasu w Polsce jest stosunkowo niski, na dodatek - przy względnej stabilności - wykazuje niewielkie tendencje do zmniejszania. Dla porównania można przywołać analogiczne wielkości w krajach Unii Europejskiej. Tam udział pracujących w niepełnym wymiarze czasu w 1990 r. i 1999 r. kształtował się na poziomie (odpowiednio): 13,3\% i 16,4\% i miał wyraźną tendencję rosnącą (wzrost o 3,1 pkt. proc., a więc o prawie jedną czwartą) (tabl. 1). Udział pracujących w niepełnym wymiarze czasu w Polsce był znacznie mniejszy: o około $1 / 3$ niższy niż Średnio w UE, trzy razy niższy niż w Holandii, dwukrotnie niższy niż w Wielkiej Brytanii. Udział ten w krajach UE był zróżnicowany: od 7,9\% w Hiszpanii do 30,4\% w Holandii (dane z 1999 r.).

Tablica 1

Udział pracujących w niepelnym wymiarze czasu w ogolnej liczbie pracujących w krajach UE i w Polsce w latach 1990-1999

\begin{tabular}{|c|c|c|c|c|c|c|c|}
\hline \multirow[t]{2}{*}{ Wyszczególnienie } & \multirow[t]{2}{*}{1990} & \multirow[t]{2}{*}{1996} & \multirow[t]{2}{*}{1997} & \multirow[t]{2}{*}{1998} & \multirow[t]{2}{*}{1999} & \multicolumn{2}{|c|}{$\begin{array}{c}\text { Zmiany w latach } \\
\text { dziewieć́dziesiąych }\end{array}$} \\
\hline & & & & & & $\begin{array}{l}\text { bezwzglẹdne } \\
\text { w pkt. proc }\end{array}$ & względne w \% \\
\hline Austria & · & 10,9 & 10,8 & 11,5 & 12,3 & 1,4 & 13 \\
\hline Belgia & 14,2 & 16,1 & 16,2 & 16,3 & 19,9 & 5,7 & 40 \\
\hline Dania & 19,2 & 16,1 & 17,1 & 17 & 15,3 & $-3,9$ & -20 \\
\hline Finlandia a) & 7,5 & 8,4 & 9,4 & 9,6 & 9,9 & 2,4 & 32 \\
\hline Francja & 12,2 & 14,3 & 14,9 & 14,8 & 14,7 & 2,5 & 20 \\
\hline Niemcy & 13,4 & 14,9 & 15,8 & 16,6 & 17,1 & 3,7 & 28 \\
\hline Grecja & 6,7 & 8 & 8,2 & 9 & $\therefore$ & 2,3 & 34 \\
\hline Irlandia & 9,8 & 14,1 & 15,2 & 18 & 18,3 & 8,5 & 87 \\
\hline Wlochy & 8,8 & 10,5 & 11,3 & 11,2 & 11,8 & 3 & 34 \\
\hline Luksemburg & 7,6 & 10,4 & 11,1 & 12,8 & 12,1 & 4,5 & 59 \\
\hline Holandia & 28,2 & 29,3 & 29,1 & 30 & 30,4 & 2,2 & 8 \\
\hline Polska a) & & . & 11,9 & 11,8 & & $-0,1$ & -1 \\
\hline Portugalia & 6,8 & 9,2 & 10,2 & 9,9 & 9,3 & 2,5 & 37 \\
\hline Hiszpania & 4,6 & 7,5 & 7,9 & 7,7 & 7,9 & 3,3 & 72 \\
\hline Szwecja & 14,5 & 14,8 & 14,2 & 13,5 & 14,5 & 0 & 0 \\
\hline Wielka Brytania & 20,1 & 22,9 & 22,9 & 23 & 23 & 2,9 & 14 \\
\hline UE & 13,3 & 15,2 & 15,7 & 15,9 & 16,4 & 3,1 & 23 \\
\hline
\end{tabular}

a) dane są oparte na faktycznie przepracowanych godzinach Źródło: [OECD 2000, Statistical Annex, s. 218] 
Wzrost znaczenia pracy w niepełnym wymiarze w latach dziewięćdziesiątych w krajach Unii Europejskiej był wyraźny - wystąpił w większości krajów. Największe jego tempo miało miejsce w Irlandii (z $9,8 \%$ do $18,3 \%$; a więc uległ prawie podwojeniu) i Hiszpanii (z $4,6 \%$ do $7,9 \%$ ).

Uważa się, iż kobiety z racji realizowanych przez siebie funkcji pozazawodowych są szczególnie skłonne do podejmowania pracy w niepełnym wymiarze czasu. Przyjrzyjmy się zatem zbiorowości kobiet pracujących w niepełnym wymiarze czasu. Analiza wyników BAEL pozwala na sformułowanie następujących wniosków.

1. Udział kobiet pracujących w niepełnym wymiarze czasu w ogóle pracujących kobiet kształtował się w badanym okresie na poziomie (średnio) 13,2\%. Był on stosunkowo stabilny: najwyższy poziom osiągnął w lutym 1997 r. $(14,2 \%)$ zaś najniższy w lutym i sierpniu $1993 \mathrm{r}$. oraz sierpniu i listopadzie $1997 \mathrm{r}$. $(12,7 \%)$ (wykres 2$)$. W tym samym czasie udział mężczyzn pracujących w niepełnym wymiarze czasu, w ogóle pracujących mężczyzn, kształtował się na poziomie (średnio) 8,5\% i miał tendencję malejącą. Udział kobiet w zbiorowości pracujących w niepełnym wymiarze czasu wynosił przeciętnie $56 \%$ i miał wyraźną tendencję rosnącą (od ok. 53\% w 1992 r. do 57\% w 1999 r.).

Wykres 2. Udzialy pracujących w niepelnym wymiarze kobiet i mẹzczyzn w zbiorowości pracujących kobiet i mężczyzn (maj 1992 - luty 1999)

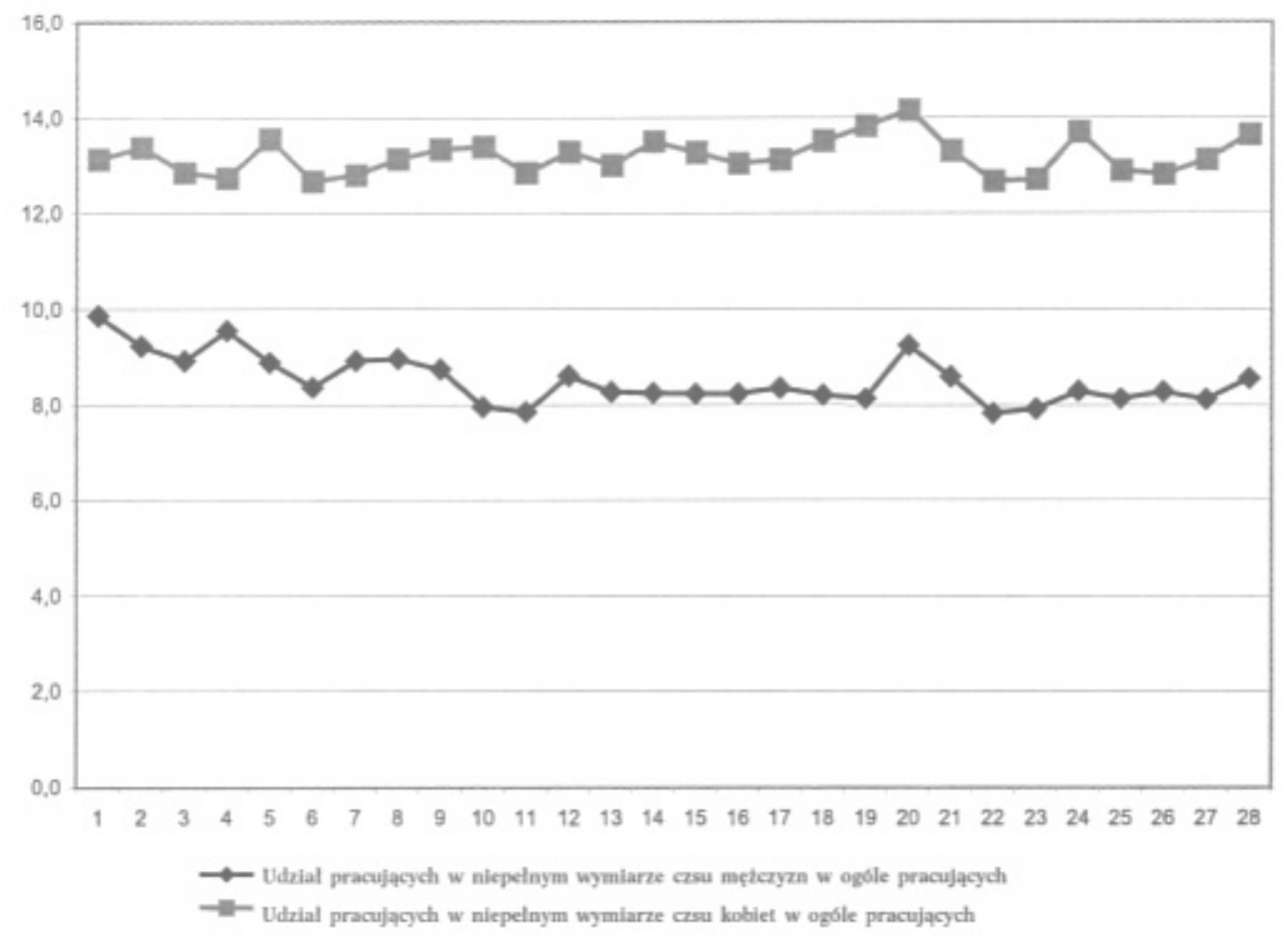

Źródło: Dane BAEL 
2. Kobiety przeważały w zbiorowości osób pracujących w niepełnym wymiarze czasu z przyczyn pozaekonomicznych $(57,6 \%)$, a zwłaszcza pracujących w tym wymiarze czasu z przyczyn osobistych (rodzinnych) $(63,1 \%)$. Jest to zgodne $\mathrm{z}$ dotychczasowymi ustaleniami w tym zakresie i postrzeganiem pracy w niepełnym wymiarze czasu jako czynnika pozwalającego z jednej strony na pogodzenie realizacji różnorodnych funkcji kobiet $\mathrm{z}$ ich aspiracjami materialnymi i pozamaterialnymi zaspokajanymi w procesie pracy.

3. Udział kobiet wśród pracujących w niepełnym wymiarze czasu z przyczyn ekonomicznych kształtowal się (średnio) na poziomie $49,5 \%$, ale wykazywał w badanym okresie wyraźną tendencję rosnącą (od. ok. 44\% w 1992 r. do ok. 52\% w 1999 r.). Szybko rósł zwłaszcza udział kobiet pracujących w niepełnym wymiarze czasu z powodu braku możliwości zdobycia pracy w większym wymiarze czasu (średni udział wyniósł $56,1 \%$, ale rósł od poziomu $41 \%$ w 1992 r. do 67,1\% w 1999 r.). Odzwierciedla to uprzywilejowaną pozycję mężczyzn na polskim rynku pracy.

Podsumowując można powiedzieć, iż dla polskich kobiet praca w niepełnym wymiarze czasu ma znaczenie względnie marginesowe. Zauważalne jest jednak, iż zatrudnienie w niepełnym wymiarze czasu, wśród kobiet częściej niż wśród mężczyzn jest "pracą ostatniej szansy", podejmowaną, kiedy brak jest moźliwości uzyskania zatrudnienia w pełnym wymiarze czasu. W tym sensie kobiety wykazują większą elastyczność i zdolność dostosowań do zmiennych warunków rynku pracy.

Porównując częstotliwość podejmowania pracy w niepełnym wymiarze czasu mężczyzn i kobiet w Polsce i w krajach wysoko rozwiniętych, dostrzec moźna wyraźne różnice (tabl. 2).

Tablica 2

Udzial mężczyzn i kobiet pracujących w niepełnym wymiarze czasu

w ogólnej liczbie pracujących mężczyzn i kobiet w Unii Europejskiej w latach 1990-1999

\begin{tabular}{|c|c|c|c|c|c|c|c|c|c|}
\hline \multicolumn{9}{|c|}{ Mężczyźni } & \multicolumn{5}{c|}{ Kobiety } \\
\hline 1990 & 1996 & 1997 & 1998 & 1999 & 1990 & 1996 & 1997 & 1998 & 1999 \\
4,2 & 5,3 & 5,7 & 5,8 & 6,0 & 27,0 & 28,7 & 29,4 & 29,8 & 30,3 \\
\hline
\end{tabular}

Źródło: [OECD 2000, Statistical Annex s. 218]

Po pierwsze, w Polsce mężczyźni częściej pracują w niepełnym wymiarze czasu niż w krajach UE: w 1999 r. zbiorowość ta stanowiła 8,6\% pracujących Polaków i $6 \%$ pracujących w UE. Zauważyć jednak trzeba, iż o ile w latach dziewięćdziesiątych w Polsce udział ten zmalał (o 1,3 pkt. proc.), to w krajach UE wzrósł (o 1,8 pkt. proc.).

Po drugie, w Polsce kobiety znacznie rzadziej korzystają z zatrudnienia w niepełnym wymiarze czasu, niż kobiety w krajach wysoko rozwiniętych: w 1999 r. udział tak pracujących Polek w zbiorowości pracujących kobiet wynosił 13,7\%. W krajach UE udział ten był znacznie wyższy: 30,3\%. W Polsce udział ten w badanym okresie był względnie stabilny, natomiast w UE rósł. 
Przyjrzyjmy się dalej, jak kształtowały się udziały niepełnozatrudnionych w zbiorowości pełno i niepełnozatrudnionych ${ }^{2}$ w Polsce w latach 1989-1999. Analiza danych pozwala na sformułowanie następujących wniosków ${ }^{3}$ :

1. Udział niepełnozatrudnionych kształtował się na poziomie (średnio) 8,6\%, przy czym miał tendencję rosnącą (najniższy poziom osiągnął w 1994 r:: 7,9\%; najwyższy w 1999 r.: 9,2\%). Należy jednak zauważyć, iż analogiczny udział w 1989 r. wynosił 10\%, a zatem był wyższy.

2. Udział niepełnozatrudnionych był ujemnie skorelowany ze stopą bezrobocia $(-0,6)$, co sugeruje, że niepełnozatrudnieni w gospodarce w tym okresie stanowili swego rodzaju „zderzak koniunkturalny” na rynku pracy.

3. Malejące tendęncje udziału niepełnozatrudnionych w zbiorowości pełno i niepełnozatrudnionych zaobserwowano jedynie w czterech sekcjach: górnictwie i kopalnictwie, zaopatrywaniu w energię elektryczną, gaz i wodę, administracji publicznej i obronie narodowej oraz pozostałej działalności usługowej $\mathrm{i}$ innej. W trzech z nich ( $\mathrm{z}$ wyjątkiem administracji publicznej i obronie narodowej) w tym okresie wystąpil spadek zatrudnienia, odbywający się również poprzez - mający szybsze tempo - spadek liczby niepełnozatrudnionych. W administracji publicznej i obronie narodowej miała miejsce inna sytuacja zwiększenie zapotrzebowania na pracę w pełnym wymiarze czasu.

4. Najwyższe udziały niepełnozatrudnionych obserwuje się w sekcjach usług: pozostałej działalności usługowej i innej, edukacji, hotelach i restauracjach, oraz obsłudze nieruchomości i firm. W trzech ostatnich występuje bardzo silna ujemna korelacja ze stopą bezrobocia $(-0,9)$ oraz najsilniejsza tendencja wzrostu udziału niepełnozatrudnionych w zbiorowości pełno- i niepełnozatrudnionych. Tam zatem występują najbardziej elastyczne dostosowania zatrudnienia do sytuacji na rynku pracy.

Również w krajach UE zatrudnienie w niepełnym wymiarze czasu koncentruje się w usługach: biznesowych, komputerowych, ochronie zdrowia i edukacji, rekreacyjnych, pocztowych, telekomunikacyjnych, pośrednictwie finansowym, transportowych, hotelarskich i gastronomicznych oraz w przemyśle drzewnym i meblarskim [OECD 1998]. W tych obszarach działalności udział ten jest około dwa razy wyższy niż przeciętnie w UE.

Podsumowując można stwierdzić, iż jakkolwiek w podmiotach zatrudniających powyżej 5 osób w Polsce w latach dziewięćdziesiątych udział niepełnozatrudnionych w zbiorowości pełno- i niepełnozatrudnionych należy oceniać jako niski, to pojawiają się pewne symptomy prób uelastycznienia zatrudnienia w drodze zmian liczby niepełnozatrudnionych. Widać to szczególnie w usługach, zwłaszcza rynkowych.

Wykorzystanie zatrudnienia w niepełnym wymiarze czasu jest formą uelastycznienia rynku pracy braną szczególnie pod uwagę w UE, gdzie firmy dą-

2 Bez zakładów osób fizycznych o liczbie pracujących do 5 osób i gospodarstw indywidualnych w rolnictwie.

3 Obliczenia własne na podstawie danych zawartych w Rocznikach Statystycznych GUS, wydania $\mathrm{z}$ odpowiednich lat. 
żą do większej swobody w zakresie angażowania i zwalniania pewnych grup pracowników mających dla przedsiębiorstw znaczenie marginalne, co jest łatwiejsze w przypadku pracowników zatrudnionych w niepełnym wymiarze czasu. Badania pracy w niepełnym wymiarze czasu w 8 krajach UE przeprowadzone w latach 1989-1990 wykazały, że [Wickham 1997]:

- $44 \%$ zatrudnionych w niepełnym wymiarze czasu pracowało tak z inicjatywy zakładu w związku z jego potrzebami,

- $31 \%$ zakładów stosowało ten system uwzględniając życzenia pracowników,

- $15 \%$ zakładów decydowało się na wprowadzenie pracy w częściowym wymiarze tylko dla wygody pracowników,

- zadaniem pracodawców, tylko $10 \%$ pracowników pracujących w pełnym wymiarze czasu domagało się przeniesienia do pracy w niepełnym wymiarze czasu,

- praca w niepełnym wymiarze czasu była często wprowadzana z przyczyn ekonomicznych, pracownicy godzili się na nią, uważając, że ułatwi ona powrót do pracy w pełnym wymiarze,

- firmy generalnie byly zainteresowane dobrowolnym wprowadzeniem pracy w niepełnym wymiarze.

\section{Praca dorywcza}

Istotną niestandardową formą powodującą uelastycznienie organizacji pracy jest zatrudnienie dorywcze (wykres 3).

Wykres 3. Udzial pracujących dorywczo wsród pracujących ogólem (maj 1992 - luty 1999)

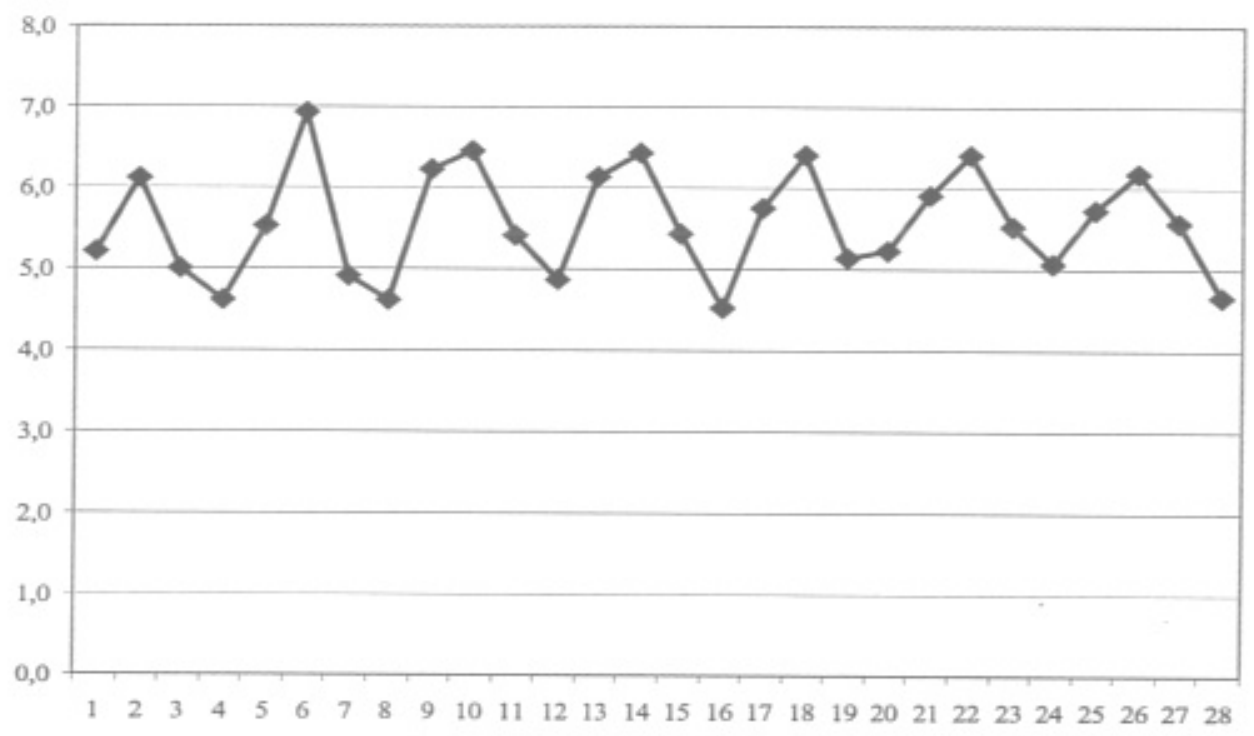

Źródło: dane BAEL 
Pracujący dorywczo stanowili w badanym okresie średnio 5,6\% pracujących ogółem. Pracujące dorywczo kobiety z kolei to $4,9 \%$ pracujących kobiet i $39,9 \%$ zbiorowości pracujących dorywczo ogółem ${ }^{4}$. Jak zatem widać - pracę dorywczą częściej podejmowali mężczyźni. Jest charakterystyczne, iż nie obserwuje się niemal żadnej tendencji rozwojowej tego zjawiska, natomiast wysoką jego zmienność sezonową: zapotrzebowanie na pracowników dorywczych jest wyższe w maju i sierpniu, natomiast niższe w listopadzie i lutym każdego roku. Jest to związane z sezonowością prac w wielu dziedzinach, takich jak np. rolnictwo, budownictwo, turystyka, gastronomia i innych.

Udział w pracach dorywczych był w badanym okresie słabo ujemnie skorelowany ze stopą bezrobocia, co wyraźnie wskazuje, iż nie są one traktowane jako element dostosowań podaży siły roboczej do sytuacji na rynku pracy, czyli jej elastyczności. Należy również zwrócić uwagę, iż pracę dorywczą najczęściej podejmują pracujący z wykształceniem podstawowym i niepełnym podstawowym $(7,1 \%)$, najrzadziej zaś pracujący z wykształceniem wyźszym $(2,5 \%)^{5}$. Jak z tego widać - im trudniejsza jest sytuacja na rynku pracy danej grupy osób, tym częściej praca dorywcza staje się substytutem pracy stałej. Pracobiorcy dostosowują się w ten sposób do niestabilności popytu, godząc się na pracę nie zaspokajającą w pełni ich oczekiwań. Naleźy także dodać, iż skłonność do podejmowania prac dorywczych dla części osób jest postawą naturalną: nie oczekują oni zatrudnienia trwałego, a przemieszczanie się między niestabilnymi miejscami pracy, przerywane okresami pozostawania bez zatrudnienia jest dobrowolnie wybranym i akceptowanym sposobem zdobywania środków utrzymania.

\section{Praca na rachunek wlasny}

Pracodawcy (samozatrudnieni angażujący pracowników), pracujący na rachunek własny (samozatrudnieni nie angażujący pracowników) oraz pomagający członkowie rodziny tworzą kategorię „samozatrudnionych”. Ponieważ w praktyce analiz tej kategorii często dokonuje się wyłączenia pomagających członków rodzin, można przyjąć, iż termin "samozatrudnieni” odnosi się do pracodawców (employers) i pracujących na rachunek własny (own-account workers) [por. OECD 2000].

Udział pracodawców i pracujących na własny rachunek (poza rolnictwem indywidualnym) w Polsce w latach 1990-1999 w ogólnej liczbie pracujących („cywilnych”6) miał zmienne tendencje kształtowania: początkowo szybko wzrastał (z 7,9\% do 12,8\%), w 1994 r. zmniejszył się znacznie (do poziomu 9,4\%)

4 Dane za okres maj 1992 r. - luty 1999 r. [GUS 1999, 1999a].

5 Współczynnik korelacji między stopą bezrobocia a udziałem pracujących dorywczo w ogólnej liczbie pracujących o danym poziomie wykształcenia kształtował się w lutym 1999 r. na poziomie 0,944 [GUS 1999a].

6 Poza jednostkami budźetowymi resortu obrony narodowej i resortu spraw wewnętrznych i administracji oraz Urzędu Ochrony Państwa. 
(wykres 4). W 1999 r. ukształtował się na poziomie 9,9\%, wykazując (od 1994 r.) niewielką tendencję wzrostową. Udział ten był dodatnio skorelowany ze stopą bezrobocia $(0,617)$, co wskazuje, iż sytuacja na rynku pracy jest bodźcem do podejmowania pracy na rachunek własny.

Wykres 4. Udział pracodawców i pracujących na wlasny rachunek poza rolnictwwem indywidualnym w ogóle pracujących w latach 1990-1999

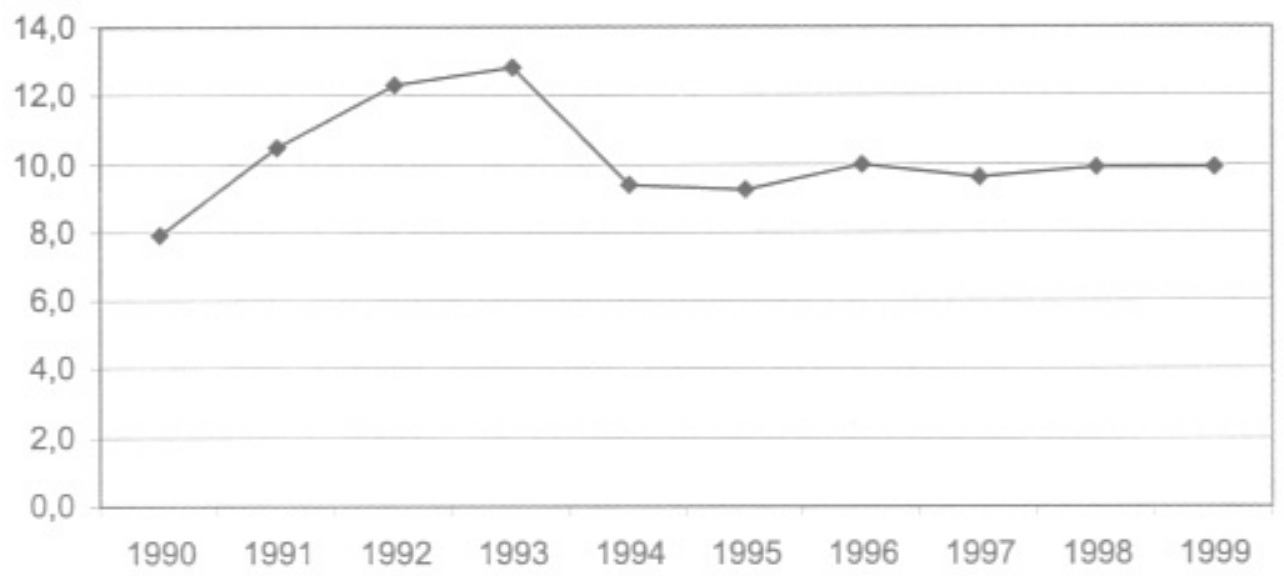

Źródlo: Roczniki Statystyczne GUS, wydania z odpowiednich lat

W UE obserwuje się wyraźnie pewne odrodzenia zjawiska samozatrudnienia. Wzrost udziału samozatrudnionych poza rolnictwem miał miejsce w latach dziewięćdziesiątych w jedenastu krajach, najsilniejszy w Holandii (z 7,8\% do $9,7 \%$ ), Szwecji (z 7,3\% do 9\%), Niemczech (z 7,7\% do 9,4\%) oraz Finlandii (z $8,8 \%$ do $10 \%)$. Spadek udziału samozatrudnionych w tym samym okresie miał miejsce we Francji (z 9,3\% do 8,2\%), Wielkiej Brytanii (z 12,4\% do $11,4 \%$ ), Grecji (z 27,4\% do $27 \%$ ) i Danii (z 7,2\% do 6,9\%) (tabl. 3).

Udział samozatrudnionych poza rolnictwem w Polsce i w krajach UE (niezależnie od pewnej nieporównywalności danych) kształtuje się podobnie. Należy jednak zauwaźyć, iż:

- Po pierwsze - odbiega in minus od udziałów samozatrudnionych w ogólnej liczbie pracujących w krajach UE, stosunkowo słabo rozwiniętych: Grecjii, Hiszpanii i Portugalii. A zatem - można postawić tezę, iż wielkość samozatrudnienia w Polsce nie jest zbyt niska do fazy rozwoju gospodarki.

- Po drugie - nie obserwuje się w Polsce wyraźnej tendencji wzrostu znaczenia samozatrudnienia.

Ekspansja pracy na rachunek własny obserwowana w Polsce w pierwszych latach transformacji była rezultatem odblokowaniem hamulców dla jej rozwoju na przełomie lat osiemdziesiątych i dziewięćdziesiątych. Istotną rolę odegrała tu wielka aktywność jednostek. Obecnie mamy do czynienia z wyraźnym zahamowaniem ekspansji przedsiębiorczości indywidualnej, co każe zwrócić 
Tablica 3

Udzial samozatrudnienia poza rolnictwem" w zatrudnieniu cywilnym w krajach UE 1 w Polsce w latach 1979.1998

\begin{tabular}{|l|r|r|r|r|r|r|}
\hline Wyszczególnienie & 1979 & 1990 & 1994 & 1996 & 1997 & 1998 \\
\hline Austria b) & 8,9 & 6,6 & 6,6 & 6,9 & 7,0 & 7,4 \\
Belgia c) & 11,2 & 12,9 & 14,1 & 14,1 & 14,1 & 13,9 \\
Dania d) & 9,2 & 7,2 & 6,8 & 7,1 & 6,7 & 6,9 \\
Finlandia d) & 6,1 & 8,8 & 9,9 & 10,3 & 10,0 & 10,0 \\
Francja d) & 10,6 & 9,3 & 8,8 & 8,5 & 8,6 & 8,2 \\
Niemcy d) & 8,2 & 7,7 & 3,5 & 9,0 & 9,2 & 9,4 \\
Grecja d) & 32,0 & 27,4 & 28,0 & 27,5 & 27,0 &. \\
Irlandia d) & 10,4 & 13,4 & 13,6 & 12,8 & 12,9 & 13,4 \\
Wlochy b) & 18,9 & 22,2 & 22,3 & 23,0 & 22,7 & 22,7 \\
Luksemburg b) & 9,4 & 7,1 & 9,3 & 9,7 & 10,0 & 9,7 \\
Holandia e) & 8,8 & 7,8 & 9,4 & 9,8 & 11,6 & 16,0 \\
Polska d) & & & 11,7 & 11,4 & 19,1 &. \\
Portugalia c) & 12,1 & 16,7 & 19,2 & 19,8 & 18,1 & 17,6 \\
Hiszpania c) & 15,7 & 17,1 & 18,7 & 18,5 & 9,0 & 9,0 \\
Szwecja d) & 4,5 & 7,3 & 9,0 & 9,1 & 11,7 & 11,4 \\
Wielka Brytania d) & 6,6 & 12,4 & 12,0 & 11,7 & & \\
\hline
\end{tabular}

a) Z wyłączeniem pomagających czlonków rodziny.

b) Klasyfikacja właścicieli spółek kapitałowych zarządzających nimi jest niejasna.

c) Włączając właścicieli spółek kapitałowych zarządzających tymi spółkami.

d) Włączając większość właścicieli spólek kapitałowych zarządzających tymi spółkami.

e) $\mathrm{Z}$ wylączeniem większości wlaścicieli spółek kapitałowych zarządzających tymi spółkami.

Źródło: [OECD 2000, s. 158].

uwagę na bariery jej rozwoju. Należą do nich przede wszystkim: brak kapitału lub/i brak przygotowania merytorycznego lub/i brak umiejętności utworzenia i prowadzenia własnej działalności lub/i brak informacji o pomocy i zobowiązań z tego wynikających. Znaczącej przeszkody, w dalszym rozwoju różnych form samozatrudnienia, upatrywać można w pierwszym rzędzie w mentalności mieszkańców kraju dla znacznej części, których tradycją było planowanie przyszłości zawodowej w jednym przedsiębiorstwie, a normalną karierą zawodową byla praca najemna. Splot zdarzeń ostatnich lat spowodował zmiany mentalności zasobów pracy w stopniu, który można ocenić jako niewystarczający. Drugą przeszkodą jest niezbyt rozbudowany i często trudno dostępny lub wręcz niedostępny system pomocy.

\section{Praca w ramach programów rynku pracy}

Realizacja aktywnych programów rynku pracy pozwala miedzy innymi na zatrudnienie bezrobotnych $\mathrm{w}$ ramach prac interwencyjnych i przy robotach publicznych. Udział tego typu bezrobotnych w zbiorowości aktywnych zawodowo przedstawia wykres 5 . 
Wykres 5. Udzial podejmujących prace interwencyjne i roboty publiczne wsród aktywnych zawodowo w latach 1992-1999

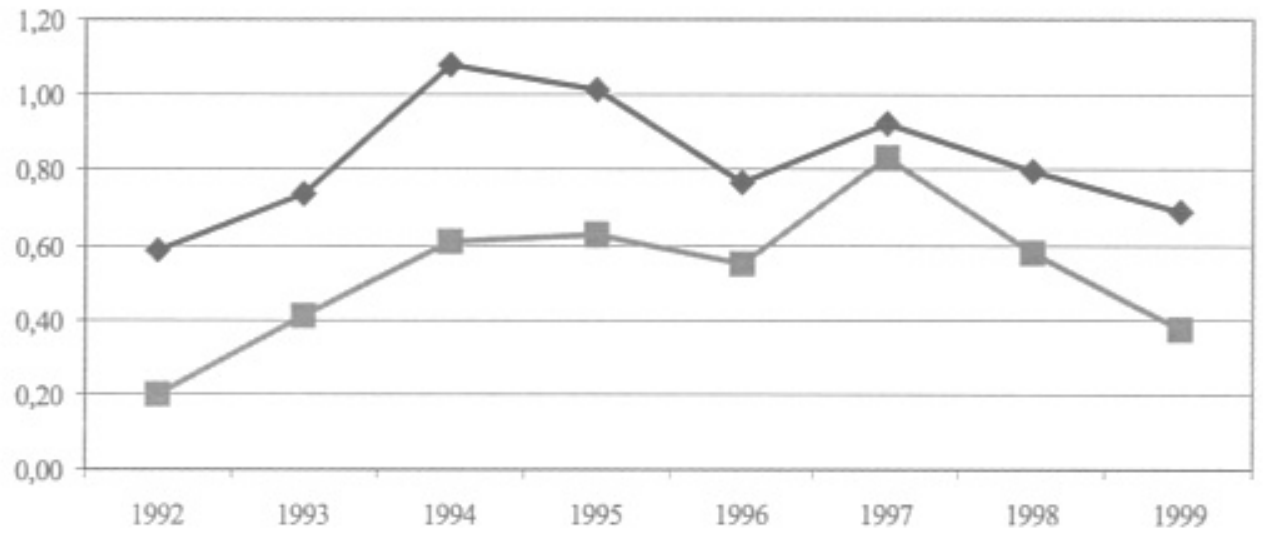

- Udzial bezrobotnych zatrudnionych przy pracach interwencyjnych wśród aktywnych zawodowo

Źródlo: Roczniki Statystyczne GUS, odpowiednie lata, obliczenia wlasne

Podejmujący prace interwencyjne stanowili w latach 1992-1999 od 0,58\% (1992 r.) do 1,08\% (1994 r.) aktywnych zawodowo (pracujących i bezrobotnych) (średnio 0,82\%). Udział ten rósł do systematycznie w latach 1992-1994, następnie zmniejszył się i w 1999 r. wyniósł 0,69\%. Analogiczny udział zatrudnionych przy robotach publicznych byl jeszcze niższy i wynosił od $0,2 \%$ (1992 r.) do 0,83\% w 1997 r. (średnio w badanym okresie udział ten wyniósł $0,52 \%)$. W sumie udział zatrudnionych przy pracach interwencyjnych i przy robotach publicznych w ogólnej liczbie aktywnych zawodowo najwyższy był w 1997 r. (1,7\%), zaś najniższy w 1992 r. (0,8\%) (średnio 1,35\%). Zwraca uwagę wyraźna tendencja malejąca udziałów uczestników obu aktywnych programów rynku pracy w zbiorowości aktywnych zawodowo w latach 1998-1999.

Ograniczony zakres zatrudnienia w ramach aktywnych programów rynku pracy powoduje $w$ Polsce, iż w nikłym stopniu wpływa ono na elastyczność dostosowań podaży i popytu na pracę. Nie taka jest zresztą ich podstawowa funkcja, koncentrująca się na aktywizacji osób bezrobotnych. Pamiętać należy jednak o tym, iž chociaż ich zadaniem jest na ogół dążenie do integracji lub reintegracji osób objętych programem do zbiorowości pracujących, przejście uczestników tych programów do standardowego zatrudnienia wcale nie jest pewne. Czas trwania programu jest dla pracodawców okresem obserwacji i analizy z punktu widzenia dalszej przydatności pracobiorcy dla firmy.

Analiza porównawcza wskazuje, iż w Polsce zarówno wielkość, jak i struktura wydatków na aktywne programy polityki rynku pracy różni się znacznie od analogicznych w krajach UE [Martin 2000]: 
- wydatki na aktywną politykę rynku pracy stanowiły 0,3\% PKB w Polsce (1996 r.), natomiast średnio w krajach UE 1,1\%7 (najwięcej w Szwecji: 2,1\%; najmniej w Luksemburgu: 0,3\%; 1997 r.);

- udział wydatków na programy aktywne w ogólnych wydatkach na politykę rynku pracy w Polsce wynosił 15\% (1996 r)), podczas gdy średnio w krajach UE $36 \%^{8}$ (najwięcej we Włoszech: $55 \%$, najmniej w Hiszpanii: 23\%; 1997 r.);

- zatrudnienie subsydiowane pochłaniało w Polsce w 1997 r. 52\% wydatków na programy aktywne, podczas gdy w średnio w UE 29\%, gdzie z kolei stosunkowo więcej środków kierowano na szkolenie zawodowe (25\%, podczas gdy w Polsce 7\%) oraz usługi publicznych służb zatrudnienia (18\%, w Polsce 7\%).

Porównując udział bezrobotnych objętych aktywnymi programami rynku pracy w zbiorowości aktywnych zawodowo w Polsce i w krajach UE w latach dziewięćdziesiątych dostrzec można z kolei, iż:

- w krajach UE miał on tendencję wyraźnie wzrostową (z 6,1\% do 10,3\%); w Polsce tendencja taka nie wystąpiła;

- w Polsce był wyraźnie niższy niż w większości krajów UE.

\section{Praca w domu oraz telepraca}

Badania wykazują, iż coraz więcej osób wykonuje pracę zarobkową w domu9 . Przyczyną takiego stanu rzeczy są zmiany zachodzące we wspólczesnych gospodarkach, a przede wszystkim proces globalizacji prowadzący do zmian strategii i organizacji wielkich korporacji ponadnarodowych oraz szybki rozwój technik i technologii oparty na rozszerzaniu komputeryzacji w przesyłaniu informacji i technologii produkcyjnych wykorzystujących komputery.

Możliwość rozpoznania skali tego typu zatrudnienia niestandardowego w Polsce jest obecnie ograniczona. Dostępne źródła pozwalają określić wielkość zbiorowości wykonujących pracę nakładczą. Zalicza się do niej osoby, z którymi zawarto umowę o wykonanie określonych czynności na rzecz jednostki zlecającej poza jej terenem (tabl. 4).

Udział osób wykonujących pracę nakładczą w Polsce w latach dziewięćdziesiątych był niewielki i mial tendencję malejącą do 1998 r. (od 0,34\% do 0,04\%), w 1999 r. wzrósł do poziomu 0,07\%. W zbiorowości osób wykonujących pracę nakładczą przeważały (z wyjątkiem 1992 r.) kobiety ${ }^{10}$.

7 Srednia nieważona, z wylączeniem Wloch.

8 Średnia nieważona, z wylączeniem Włoch.

9 Jako kryterium wyróżniające pracę w domu przyjmuje się najezęściej lokalizację pracy, stosunek do osoby zlecającej i charakter zajęcia [Felstead, Jewson 1997, 2000].

10 Badania podjęte w Wielkiej Brytanii w grupie 15,6 tys. osób pracowników przemysłu przetwórczego pracujących w domu wykazały, że $91 \%$ wśród nich stanowily kobiety, na ogół zamężne i posiadające dzieci [Felstead, Jewson 1997]. 
Osoby wykonujące pracę nakladczą w Polsce w latach 1990-1999

\begin{tabular}{|l|c|c|c|c|c|c|c|c|c|c|}
\hline Wyszczególnienie & 1990 & 1991 & 1992 & 1993 & 1994 & 1995 & 1996 & 1997 & 1998 & 1999 \\
\hline $\begin{array}{l}\text { Udzial wśród pracujących } \\
\text { _cywilnych" }\end{array}$ & 0,34 & 0,16 & 0,11 & 0,09 & 0,08 & 0,06 & 0,05 & 0,04 & 0,04 & 0,07 \\
\hline $\begin{array}{l}\text { Udzial kobiet wśród osób } \\
\text { wykonujacych pracę } \\
\text { nakładcza }\end{array}$ & 70,0 & 65,2 & 48,8 & 60,9 & 65,0 & 67,0 & 63,9 & 67,6 & 66,7 & 61,8 \\
\hline
\end{tabular}

Źródło: Roczniki Statystyczne GUS, wydania z odpowiednich lat, obliczenia wlasne

Telepraca w Polsce jest jeszcze słabo rozwinięta. Podstawową barierą jej rozwoju jest ograniczony dostęp do internetu (szacuje się, iż w Polsce na 1000 osób są 4 komputery podłączone do tej sieci, podczas gdy w Finlandii 100). Jak wynika z oceny ekspertów Komisji Europejskiej, w Polsce telepraca stosowana jest przede wszystkim w małych firmach w celu obniżenia kosztów, rozwija się najszybciej w usługach informacyjnych i doradczych oraz w wydawnictwach, stosunkowo popularna jest również wśród księgowych i tłumaczy [Koptas-Górzańska 2000].

Tymczasem zatrudnienie w formie telepracy rosło w ostatnich latach w świecie bardzo szybko: w USA obejmuje obecnie blisko $30 \%$ zatrudnionych, zaś w krajach Unii Europejskiej ok. 6\% (ponad 9 mln pracujących). Wśród krajów UE telepraca najczęściej podejmowana jest w Szwecji i Finlandii (po ok. $15 \%$ całej siły roboczej), w Holandii (14\%) oraz w Danii i Belgii (po ok. 11\%), Stosunkowo najrzadziej telepraca podejmowana jest w Hiszpanii, Portugalii i Grecji (ok. 2\%). W krajach tych jest dopiero na etapie prób i eksperymentów. Prognozy przewidują, iż liczba telepracowników w UE do 2007 r. zwiększy się do $40 \mathrm{mln}$ [Koptas-Górzańska 2000].

W tej sytuacji rozwój technologii informacyjnych staje się siłą napędową wzrostu zatrudnienia w UE. Już obecnie sektor ten zatrudnia ponad $4 \mathrm{mln}$ osób. Stworzono w nim w latach 1995-1997 ponad 300 tys. nowych miejsc pracy, co oznacza, że co czwarte nowe miejsce pracy w UE powstało dzięki rozwojowi technologii informacyjnych [Ladwig, Domsch, Kleiminger 2000].

\section{Podsumowanie}

Analizy oparte na danych statystycznych wskazują, iż elastyczność polskiego rynku pracy rozumiana jako elastyczność popytowa (oferowanie niestandardowych form zatrudnienia i organizacji pracy) i elastyczność podażowa (gotowość do ich podejmowania) w latach dziewięćdziesiątych była niewielka, a tendencje do jej zwiększania rysowały się (w zależności od źródła danych) albo słabo, albo nie było ich w ogóle:

- odsetek pracujących w niepełnym wymiarze czasu był stosunkowo niski, na dodatek wykazywał niewielkie tendencje do zmniejszania; 
- podejmowanie pracy w niepełnym wymiarze czasu najczęściej powodowane było z powodów pozaekonomicznych, a zatem - jak należy domniemywać - było w pełni akceptowane i wynikało ze świadomego wyboru, a nie z prób dostosowywania się do trudnej sytuacji na rynku pracy;

- również dla kobiet praca w niepełnym wymiarze czasu miała charakter względnie marginesowy, z tym iż częściej niż w zbiorowości ogółem była „pracą ostatniej szansy”, podejmowaną, kiedy brak było możliwości uzyskania zatrudnienia w pełnym wymiarze czasu; w tym sensie kobiety wykazywały większą elastyczność i zdolność dostosowań do zmiennych warunków rynku pracy;

- w podmiotach zatrudniających powyżej 5 osób udział niepełnozatrudnionych w zbiorowości pełno- i niepełnozatrudnionych należy oceniać jako niski, pojawiały się jednak pewne symptomy prób uelastycznienia zatrudnienia w drodze zmian liczby niepełnozatrudnionych; widać to było szczególnie w usługach, zwłaszcza rynkowych;

- stabilny, dość niski był udział pracujących dorywczo w ogólnej liczbie pracujących, udział ten wyraźnie malał wraz ze wzrostem poziomu wykształcenia pracujących;

- udział pracodawców i pracujących na własny rachunek (poza rolnictwem indywidualnym) był również stosunkowo niski, jak na tę fazę rozwoju gospodarczego;

- ograniczona byla skala zatrudnienia w ramach aktywnych programów rynku pracy co powodowało, iż w nikłym stopniu wpływało ono na elastyczność dostosowań podaży i popytu na pracę.

Badania ankietowe pracobiorców potwierdzają diagnozę o niskiej gotowości podejmowania niestandardowych form zatrudnienia. Jak wykazaly badania przeprowadzone w 1998 r. pracobiorcy zdecydowanie preferowali zatrudnienie w pełnym wymiarze czasu, o stałych godzinach pracy. Tylko $38 \%$ wybrałoby pełny wymiar godzin pracy przy elastycznym czasie pracy; $6,5 \%$ zdecydowałoby się na zatrudnienie w niepełnym wymiarze czasu a 3,1\% zatrudnienie na kontraktach czasowych [Kukulak-Dolata 2000].

Wśród pracujących w Polsce dominuje tradycyjny pogląd na formy świadczenia pracy, zamykający się w następującym schemacie: zatrudnienie na czas nieokreślony, ośmiogodzinny dzień pracy, stałe godziny zatrudnienia. Dominacja przywiązania do tradycyjnych form świadczenia pracy jest - jak się wydaje - wywolana głównie:

- przyzwyczajeniem do takiego zatrudnienia, traktowanego jako pewnego rodzaju norma;

- częstą nieznajomością elastycznych form zatrudnienia;

- traktowaniem elastycznych form zatrudnienia jako przymusowych, narzuconych i (nie bez słuszności) gorszych;

- ogólnie niskim poziomem płac i zamożności oraz niewielkimi zasobami oszczędności społeczeństwa, co utrudnia akceptacjẹ zatrudnienia świadczonego przez krótki okres za część wynagrodzenia. 


\section{Elastyczność czasu pracy}

Badania przeprowadzane w krajach wysoko rozwiniętych nie wskazują jednoznacznie, iż skracanie czasu pracy może być jednym ze środków ułatwiających przystosowanie zatrudnienia do recesji gospodarczej, zastępując zwalnianie pracowników. Tendencje takie obserwowano w krajach UE, gdzie w latach siedemdziesiątych i osiemdziesiątych skracanie czasu pracy było szeroko stosowaną metodą, która miała przynieść wzrost zatrudnienia i redukcję bezrobocia. W latach dziewięćdziesiątych nastąpiło spowolnienie tempa skracania czasu pracy (z wyjątkiem Niemiec i Holandii), a rządy - z wyjątkiem Francji, gdzie czas pracy został skrócony od 1 stycznia 2000 r. - wycofały się z legislacyjnego skracania długości tygodnia pracy [Borkowska 2000].

Rzecz w tym, iż redukcja czasu pracy połączona ze zmniejszaniem zarobków może przynieść korzyści, o ile jest akceptowana przez pracowników i właściwie przeprowadzona. Naleźy jednak podkreślić (na co wskazują wyniki badań przeprowadzonych w Niemczech), iż zmiany liczby przepracowanych godzin w skali całej gospodarki nie mają większego wpływu na zatrudnienie i nie mogą słuźyć jako instrument ograniczenia bezrobocia. Czynnikiem oddziaływującym na sytuację na rynku pracy nie są zmiany ogólnego czasu pracy, a liczby godzin przepracowanych przez jednego pracownika. Mechanizmem mogącym przyczynić się do uelastycznienia czasu pracy jest system indywidualnych kont czasu przepracowanego. W praktyce funkcjonują dwa rodzaje kont czasu - zwykłe i długookresowe. Konta zwykłe to tradycyjne rozliczanie czasu pracy w skali miesiąca, natomiast konta długookresowe są rozliczane w dłuższych przedziałach, z uwzględnieniem - w pewnych sytuacjach - prawa decyzji pracownika. Ten rodzaj kont może być stosowany tylko wobec pracowników na stanowiskach samodzielnych. Stosowanie tego systemu może zwiększać elastyczność zatrudnienia i pozwala na suwerenne gospodarowanie czasem pracy [Betriebliche 1997].

Coraz częściej rozważane jest więc uelastycznienie indywidualnego czasu pracy, zwiększające efektywność zatrudnienia, lepsze wykorzystanie parku maszynowego. Powinny to uwzględniać ramy prawne czasu pracy, stwarzając możliwość jego regulowania w układach taryfowych, zgodnie z potrzebami branży i porozumieniami zakładowymi [Betriebliche 1997, Hofmann 1997].

\section{Konsekwencje wzrostu elastyczności zatrudnienia}

Elastyczne formy zatrudnienia i organizacji pracy są sposobem dostosowywania zarówno podażowej i popytowej strony rynku pracy do zmian systemowych i koniunkturalnych. W nich upatruje się jednego ze sposobów rozwiązywania problemów nierównowagi rynku pracy. Są również sposobem aktywizacji zawodowej osób, którym z różnych względów trudno byłoby podjąć pracę stałą, na czas nieokreślony w pełnym wymiarze czasu. 
Należy jednak zwrócić uwagę, iż tworzone tą drogą miejsca pracy często cechują niekorzystne właściwości: są niżej opłacane, mniej stabilne, nie dają możliwości identyfikacji z firmą i pracodawcą, możliwości dokształcania i awansu zawodowego, nie zapewniają poczucia stabilizacji zawodowej. Nietypowe formy zatrudnienia, wiążąc się z pojęciem zajęć pomocniczych, mogą oznaczać dla wielu pracowników najemnych wzrastającą niepewność egzystencji, niższe uposażenie i uzależnienie od fluktuacji gospodarczych. W Hiszpanii podjęto badania dotyczące pracujących dorywczo, na czas określony ${ }^{11}$. Jest to forma zatrudnienia tam szczególnie propagowana jako zwiększająca elastyczność rynku pracy i wzrost zatrudnienia. Badania w okresie 1987-1996 pozwoliły ujawnić jej uboczne konsekwencje: niskie poczucie bezpieczeństwa w sferze pracy oraz krótki kontakt z pracodawcą utrudniający doskonalenie zawodowe i obniżający wydajność pracy. Zauważono, iż zatrudnienie dorywcze prowadzi do permanentnego uzależnienia od prac okresowych, bez szans na zatrudnienie stałe. Dotyczy to zwłaszcza ludzi młodych z niskimi kwalifikacjami i kobiet [Alba-Ramirez 1998].

Najważniejszą konsekwencją szerokiego stosowania elastycznych form zatrudnienia i organizacji pracy dla rynku pracy może być nasilenie procesu jego segmentacji, będącej - jak wynika z dociekań teoretycznych - rezultatem kombinacji nierównych warunków zatrudnienia i nierównych szans dostẹpu do heterogenicznych miejsc pracy. Dokonuje się to poprzez zmniejszenie udziału w popycie na pracę dobrych, stabilnych, dających możliwość identyfikacji z firmą miejsc zatrudnienia a zwiększenie udziału miejsc pracy nie gwarantujących stałego stosunku pracy, gdzie równocześnie ograniczona jest możliwość awansu zawodowego, często towarzyszy temu niższe wynagrodzenie, silna zależność dochodów z pracy od koniunktury gospodarczej itp. Zwiększa się w ten sposób obszar tzw. drugiego (secondary), a zmniejszy pierwszego (primary) rynku pracy.

Procesy segmentacyjne zachodzą przy tym zarówno w skali krajowego rynku pracy, jak i wewnętrznych rynków pracy przedsiębiorstw, gdzie polegają na podziale ogółu pracowników na część zasadniczą, „trzon” załogi (Stammbelegschaft) oraz jej część marginesową (Randbelegschaft)12. Istnienie tych dwóch obszarów zakładowego rynku pracy stało się dominującym sposobem rozwiązywania problemów dostosowania zatrudnienia do zmieniającej się pod wpływem zmian popytu wielkości produkcji. Grupa zasadnicza to pracownicy posiadający kwalifikacje zawodowe związane ściśle z rodzajem działalności zakładu, charakteryzujący się dużą stabilnością zatrudnienia, wysoko oplacani, mający

11 W Hiszpanii w 1996 r. pracujący dorywczo stanowili aż jedną trzecią pracujących. Jest to wynikiem z jednej strony popierania elastycznego rynku pracy, a z drugiej - oporu związków zawodowych i „insiderów" przed obniženiem (bardzo wysokich w tym czasie) kosztów zwolnień z pracy [Alba-Ramirez 1998].

12 Problem segmentacji wewnętrznych rynków pracy będącej skutkiem procesów dostosowawczych przedsiębiorstw do zmiennych warunków na rynkach produktów i ich konsekwencji dla pracobiorców wyczerpująco został opisany przez badaczy niemieckich, zob. [Kōhler, Preisendörfer 1988 oraz Sengenberger 1990a i 1990b]. 
otwarte możliwości awansu. Marginesową część załogi tworzą pracownicy, na kwalifikacje których zapotrzebowanie jest zmienne, krótkoterminowe, zależne na przykład od koniunktury. Zatrudniani są oni na ogół na krótkoterminowe umowy, nie obejmujące przywilejów reszty załogi. Chodzi tu o brak formalnie zagwarantowanej stałości zatrudnienia wraz z konsekwencjami tej sytuacji w postaci zabezpieczenia emerytalnego, opieki zdrowotnej i innych korzyści zastrzeżonych w stałych kontraktach. Grupa ta z natury rzeczy jest nieustabilizowana zawodowo, funkcjonuje jako tzw. „zderzak” (Puffer, hire end fire) zatrudnienia. Zasadnicze mechanizmy dostosowawcze w przedsiębiorstwach polegają na zmianach liczby przyjęć i zwolnień z pracy przede wszystkim tej grupy pracowników, natomiast nie na przemianach wysokości i struktury płac. Wewnętrzne relacje płacowe są stałe, niezależnie od podaży kwalifikacji na zewnętrznych rynkach pracy. Segmentacja mająca miejsce na wewnętrznym rynku pracy nie ma charakteru wyłącznie endogenicznego, nie wynika (a przynajmniej nie jedynie) z zachodzących na nim procesów autonomicznych, ale najczęściej jest indukowana i podtrzymywana przez pracodawców oraz część pracobiorców dla uzyskania względnego uniezależnienia się od warunków zewnętrznych.

Dla pracobiorcy najważniejszą konsekwencją segmentacji rynku pracy jest ograniczona możliwość dostępu do pożądanych przez siebie miejsc zatrudnienia w wyniku selekcyjnego postępowania pracodawców, kierujących się przy wyborze i ocenie pracowników niezmienialnymi cechami kandydatów, takimi jak płeć, wiek, narodowość, rasa itp. Do dobrych, stabilnych miejsc pracy utrudniony dostęp mają przez to określone kategorie siły roboczej, nie będące tym samym w stanie udowodnić swojej przydatności.

Nie ulega wątpliwości, że zmiany zachodzące na współczesnych wewnętrznych rynkach pracy nie są obojętne dla pracobiorców, których różne grupy są odmiennie traktowane przez pracodawców. Podstawowe z punktu widzenia przedsiębiorstwa grupy o wysokich kwalifikacjach są zatrudniane według tradycyjnych zasad, natomiast grupy o znaczeniu peryferyjnym są zatrudniane w różnych formach zubożonych, niepełnych, pozwalających na elastyczność strategii w zależności od sytuacji na rynku produktów. Rachunek ekonomiczny firm powoduje, że w krajach wysoko rozwiniętych udział osób zatrudnionych na podstawie takich „zuboźnych" umów o pracę rośnie.

Istnieje wiele przesłanek wskazujących na potrzebę zwiększenia elastyczności zatrudnienia w Polsce. Przedstawienie jej negatywnych konsekwencji nie miało na celu przeciwstawienie się adaptacji na polskim rynku pracy nowych tendencji obserwowanych na rynkach pracy krajów wysoko rozwiniętych. Są tylko spostrzeżeniem badacza, próbującego dokonać antycypacji możliwych (zwłaszcza negatywnych) zjawisk, jakie w przyszłości mogą się pojawić na polskim rynku pracy. Należy się do nich przygotować wcześniej, by we właściwym czasie podjąć działania adekwatne do nasilenia mogących się pojawić skutków.

Zwiększanie elastyczności polskiego rynku pracy w drodze poprawy elastyczności zatrudnienia rodzi tym samym niezwykle ważny problem wypraco- 
wania sposobów uzyskania przyzwolenia ze strony partnerów społecznych. Doświadczenia krajów UE pokazują, iż wymaga to czasu i negocjacji, ponieważ wiẹkszość form elastycznych prowadzi do utraty dotychczasowych przywilejów pracowniczych. Istota zagadnienia tkwi jednak w tym, by wszyscy aktorzy rynku pracy bez wyjątku podejmowali starania w celu ułatwienia i zachęcania do powstawania nowych miejsc pracy, choćby mniej atrakcyjnych, ale gwarantujących moźliwość zatrudnienia.

\section{Bibliografia}

Adnett N., [1996], European Labour Markets: analysis and policy, Longman, London and New York.

Alba-Ramirez A., [1998], How temporary is temporary employment in Spain, Journal of Labor Research $\mathrm{Nr} 4$.

Betriebliche Arbeitszeitpolitik, [1997], Personal $\mathrm{Nr} 7$.

Bielensky H., [1993], Betriebliche Erfahrungen mit atypischen Arbeitsformen. Ergebnisse einer Repräsentativerhebung in acht europäischen Ländem, (w:) Mitteilungen aus der Arbeitsmarktund Berufsforschung No 3, Verlag W. Kohlhammer, Stuttgart, Berlin, Köln, Meinz.

Borkowska S., [2000], Elastyczne formy zatrudnienia. Trendy rozwojowe, maszynopis.

Chobot A., [1997], Nowe formy zatrudnienia. Kierunki rozwoju i nowelizacji, Wydawnictwo Prawnicze PWN, Warszawa.

Felstead A., Jewson N., [1997], Researching a problematic concept: homeworkers in Britain, Work Employment Society $\mathrm{Nr} 2$.

Felstead A., Jewson N., [2000], In work, at home: towards an understanding of homeworking, Routledge, London, New York.

GUS [1999], Aktywność ekonomiczna ludności Polski w latach 1992-1998, Informacje i Opracowania Statystyczne, GUS, Warszawa.

GUS [1999a], Aktywność ekonomiczna ludnosci Polski, luty 1999, Informacje i Opracowania Statystyczne, Glówny Urząd Statystyczny, Warszawa.

Hofmann C.F., [1997]. Für mehr Beschäftigung, Bundesarbeitsblatt $\mathrm{Nr} 6$.

Köhler Ch., Preisendörfer P., [1988], Innerbetriebliche Arbeitsmarktsegmentation in Form von Stammund Randbelegschaften. Emipirische Befunde aus einem bundesdeutschen Grossbetrieb, (w:) Mitteilungen aus der Arbeitsmarkt- und Berufsforschung No 2, Verlag W. Kohlhammer, Stuttgart, Berlin, Köln, Meinz.

Koptas-Górzańska G., [2000], Europa nam ucieka, Rzeczpospolita nr 126 (5596) z 31 maja.

Kukulak-Dolata I., [2000], Mobilność miẹdzyzaktadowa, (w:) E. Kryńska (red.) Mobilność zasobów pracy. Analiza i metody stymulacji, IpiSs, Warszawa.

Kühl J., [1990], New deal and new forms of employment, Labour and Society, Vol. 15, No. 2.

Ladwig D.H., Domsch M.E., Kleiminger K., [2000], Temporary Work and Tele-Work, (w:) Exploring Trends in Employment Relations and New Approaches to Work in the Twenty-First Century, $12^{\text {th }}$ World Congress, Tokio.

Martin J.P., [2000], What works among active labour market policies: evidence from ORCD Countries' experiences, OECD Economic Studies No. 30.

OECD [1998], Empolyment Outlook, Paris.

OECD [2000], Empolyment Outlook, Paris.

Pocztowski A., [1994], Nietypowe formy zatrudnienia, Gospodarka Narodowa Nr 9.

Rosenberg S., [1989], Labor Market Restructuring in Europe and the United States: The Search for Flexibility, (w:) S. Rosenberg (red.) The State and the Labor Market, Plenum Press, New York - London. 
Sengenberger W., [1990a], Flexibility in the Labor Market - Intemal versus Extemal Adjustment in Intemational Comparison, (w:) Schettkat R., Appelbaum E. (red.) Labor Market Adjustments to Structural Change and Technological Progress, New York.

Sengenberger W., [1990b], Das „amerikanische Beschäftigungswunder" als Vorbild? - interne versus exteme Flexibilität am Arbeitsmarkt, (w:) Büchtemann Ch., Neuman H. (red.) Mehr Arbeit durch weniger Recht? Chancen und Risiken der Arbeitsmarktflexiebilisierung, Sigma Bohn, Berlin.

Solow R.M., [1998], What is Labout Market Flexibility? What is it Good For?, Proceedings of the British Academy, Vol. 97.

Wickham J., [1997], Part-time work in Ireland and Europe: who wants what where?, Work Employment Society $\mathrm{Nr} 1$.

Wiśniewski Z., [1999]. Kierunki i skutki deregulacji rynku pracy w krajach Unii Europejskiej, Uniwersytet Mikołaja Kopernika, Toruń. 